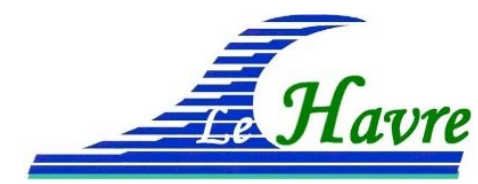

XVI èmes Journées Nationales Génie Côtier - Génie Civil

Le Havre, 2020

DOI:10.5150/jngcgc.2020.075 C Editions Paralia CFL

disponible en ligne - http://www.paralia.fr - available online

\title{
Video monitoring of Posidonia oceanica banquettes on pocket beaches, Northern Corsica
}

\author{
Anne-Eléonore PAQUIER ${ }^{1}$, Thibault LAIGRE ${ }^{2}$, Rémi BELON ${ }^{3}$, \\ Yann BALOUIN ${ }^{4}$, Nico VALENTINI ${ }^{4}$, Julie MUGICA ${ }^{1}$
}

1. BRGM Corse, Immeuble Agostini, Zone Industrielle de Furiani, 20600 Bastia. ae.paquier@brgm.fr

2. BRGM Guadeloupe, Parc d'activités Colin - La Lézarde, 97170 Petit Bourg.

3. BRGM La Réunion, 5 rue Sainte-Anne - CS 51016, 97404 Saint-Denis Cedex.

4. BRGM-Université de Montpellier, 1039 Rue de Pinville, 34000 Montpellier.

\begin{abstract}
:
Fragments of Posidonia oceanica accumulate on beaches and can form structures composed of seagrass and sediments of variable heights and extents, called banquettes. Coastal video-monitoring tools were used on pocket beaches of the Cape Corse to investigate the dynamics of these banquettes and evaluate their role against beach erosion. On Pietracorbara beach and Meria beach, these banquette dynamics reflect those of pocket beaches: beach and banquette rotations are monitored. On the three sites, the dynamics of the banquette is thus controlled by wave direction and wave energy, i.e. when a threshold of wave height is reached, the banquette is destroyed. On Ostriconi beach, the $P$. oceanica litter is moved back and forth from the water to the shore by waves through rip current channels. The banquette is thus building on specific areas of the beach corresponding to the exit of the channels.

$P$. oceanica litter has a protective role when ashore (buffer between the beach sediments and the wave impact) and in the water also (modification of wave breaking). Further measurements would be needed to confirm these results and to analyze them with respect to local hydrodynamics. These first results can still provide useful insights on the phenomena and further information to local administrators for beach management.
\end{abstract}

Keywords:

Posidonia oceanica, Banquette, Video monitoring, Coastal management, Nature-Based Solutions

\section{Introduction}

Posidonia oceanica is a marine phanerogam endemic of the Mediterranean which extent in large meadows from 0 to $-45 \mathrm{~m}$ water depth (BOUDOURESQUE et al., 2009; PERGENT et al., 2012). Fragments of $P$. oceanica accumulates on beaches and can form structures composed of seagrass and sediments of variable heights and extents called banquettes (SIMEONE \& DE FALCO, 2013). Previous studies described these deposits (MATEO et al., 2003), their morphology and composition (DE FALCO et al., 2008) and 


\section{Thème 6 - Gestion durable des zones littorales et estuariennes}

the role of their removal on beaches (SIMEONE \& DE FALCO, 2012). More recently, the POSEMED project analysed the perception of the presence of banquettes on the shore and possible management strategies (MOSSONE et al. 2019). Except for one study (GOMEZ-PUJOL et al., 2013), the dynamics of banquettes have not been investigated even though they are generally recognized to protect beaches against erosion. Nowadays, the use of video monitoring is very appealing for the understanding of coastal dynamics (HOLLAND \& HOLMAN, 1997; BALOUIN et al., 2004; ALMAR et al., 2009; VALENTINI et al., 2017) and coastal vegetation dynamics (VALENTINI \& BALOUIN, 2020). These methods were used on pocket beaches of the Cape Corse to investigate the dynamics of $P$. oceanica banquettes and evaluate their role against beach erosion. This communication aims to present the results of this study and to analyse them in regards of banquette management.

\section{Material and methods}

\subsection{Study site}

Cameras were implemented above three pockets beaches of the Cape Corse (northern part of Corsica, figure 1, a.): Ostriconi beach, located on the West coast, exposed NNW, 750 $\mathrm{m}$ long and $30 \mathrm{~m}$ large, composed of fine to medium sand, stable on the historical period; Pietracorba beach, located on the East coast, exposed E, $550 \mathrm{~m}$ long and 20 to $30 \mathrm{~m}$ large, composed of fine to medium sand, in erosion on the historical period; Meria beach, 15 $\mathrm{km}$ North of Pietracorbara, exposed ESE, $230 \mathrm{~m}$ long and less than $20 \mathrm{~m}$ large, composed of medium to coarse sand, in erosion on the historical period (BALOUIN \& BELON, 2014). These three sites are affected by $P$. oceanica banquettes in winter.

\subsection{Material and methods}

The low-cost SolarCam systems ${ }^{\circledR}$ (https://www.solarcam.fr/) were installed considering several implementation parameters: distance to the beach (acceptable resolution), height above the water (transposition into an orthonormal coordinate system), direction (sun reflection), stability and safety of the camera. They recorded discontinuously from March 2016 to May 2017 (Ostriconi: 17/03-09-06/2017; Pietracorbara: 11/02-08/08/2016, 30/01-14/03/2017; Meria: 19/01-13/12/2017) at a rate of one frame per minute to one frame every ten minutes. The images were processed using Matlab ${ }^{\circledR}$ tools developed for coastal monitoring (VALENTINI et al., 2019). 


\section{XVİ̀mes Journées Nationales Génie Côtier - Génie Civil \\ Le Havre 2020}
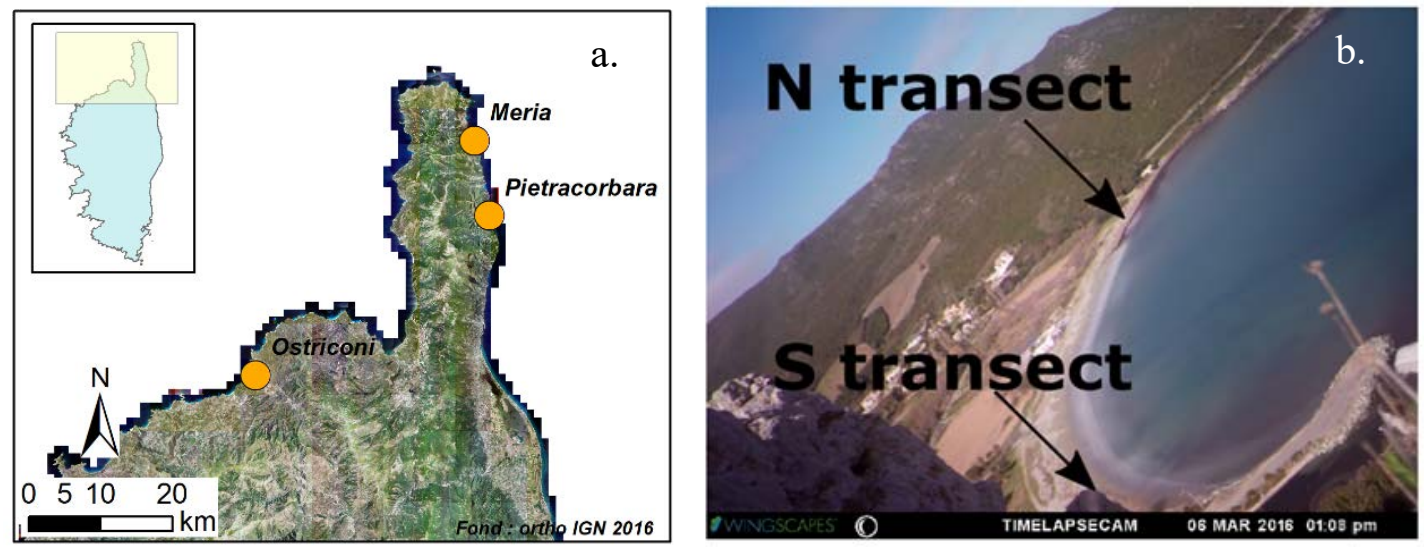

Figure 1. a. Location of the three study sites and $b$. location of the transects studied at Pietracorbara beach.

The images were rectified (transposed into an orthonormal coordinate system) and georeferenced using ground control points previously measured with a DGPS Trimble ${ }^{\circledR}$ R6. Shorelines were extracted using the blue/red ratio at different dates (ALMAR et al., 2009; BRYAN et al., 2013) and compared with DSAS®. Reliability of these shorelines was evaluated from comparison with concomitant DGPS measurements (table 1).

Table 1. Range of metric gaps in positioning between the DGPS-measured shorelines and the shoreline extracted from the images.

\begin{tabular}{|l|l|l|l|}
\hline Sites & Minimum & Mean & Maximum \\
\hline Pietracorba & $<1$ & 1.75 & 4.25 \\
\hline Meria & 1 & 4 & 8 \\
\hline Ostriconi & $<1$ & 5 & 16 \\
\hline
\end{tabular}

In the absence of local measurements, $\mathrm{Hs}$, Tp and wave direction at the sites were extracted from the WAM model (THE WAMDI GROUP, 1988). The gaps between the model and the measurements at the Candhis buoys (Alistro and La Revellata) are higher on the East coast than on the West coast of Corsica. Moreover, the values extracted at the study sites are calculated on cells from a large mesh; the gaps at the coast can be high. For these reasons, only trends will be considered. Timestacks along chosen beach transect were built and compared to these hydrodynamic conditions.

\section{Results and discussion}

\subsection{Beach and banquette rotation}

Over the survey period, 21 events with $\mathrm{H}_{\mathrm{s}}>1.5 \mathrm{~m}$ were monitored. Three events and their consequences on the banquette at Pietracorbara beach are shown in figure 2 . 


\section{Pietracorbara, 04-07/03/2016}

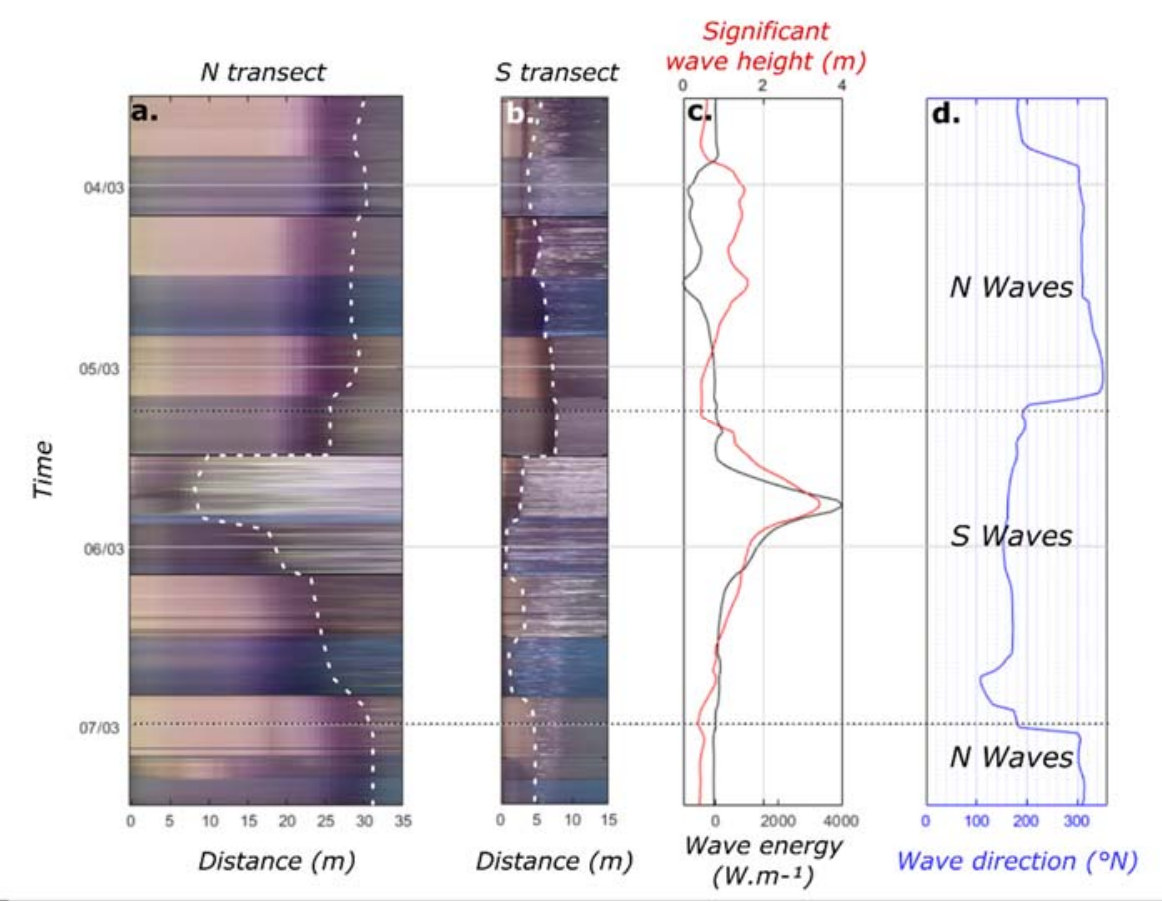

Pietracorbara, 11-15/03/2016

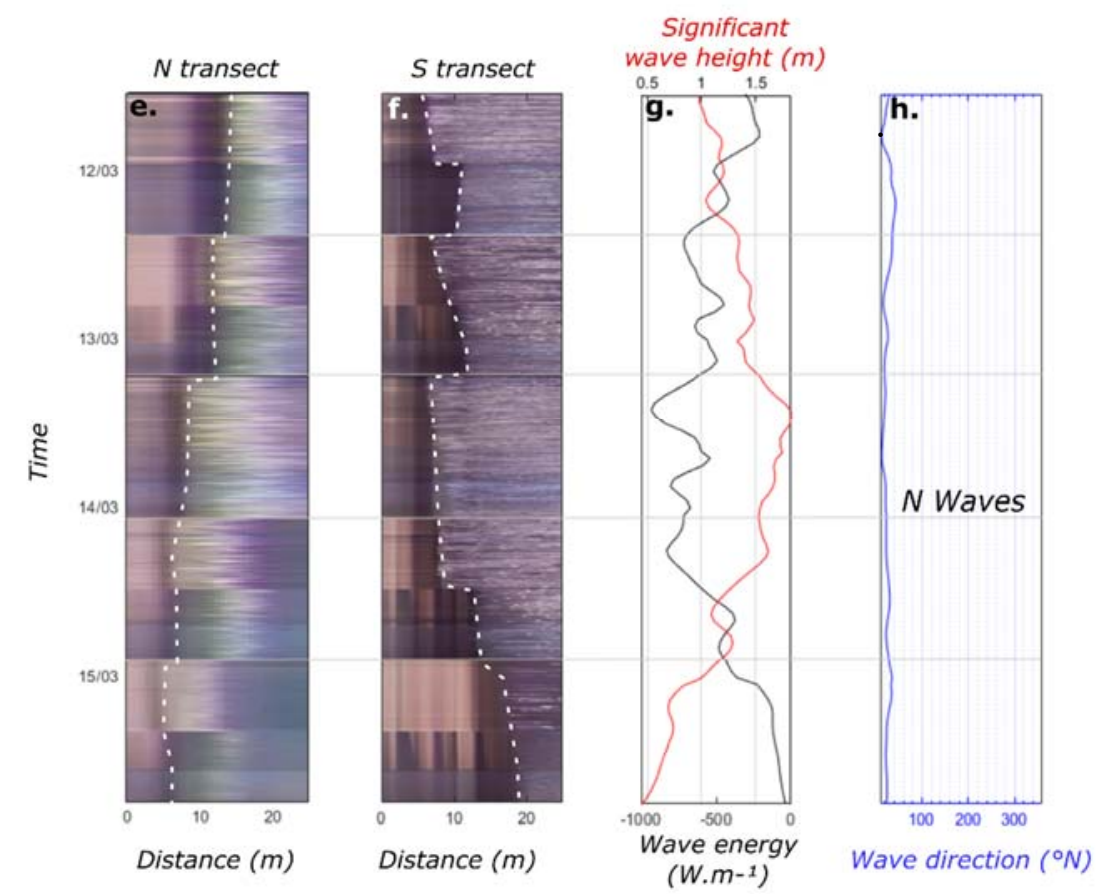

Figure 2. a. b. e. and f. Temporal evolution of pixel intensity profile of $N$ transect and $S$ transect (figure 1, b.). The white dotted lines show the shoreline, the darkest areas represent the banquettes. $c$. and $g$. wave height and energy; $d$. and $h$. wave direction at Pietracorba beach over the two periods compared (upper line: 04-07/03/2016 and bottom line: 11-15/03/2016). 


\section{XVİ̀mes Journées Nationales Génie Côtier - Génie Civil \\ Le Havre 2020}

$\mathrm{N}$ waves were recorded (maximum $\mathrm{H}_{\mathrm{s}}=1.8 \mathrm{~m}$, figure 2, c.) quickly followed by $\mathrm{S}$ waves (maximum $\mathrm{H}_{\mathrm{s}}=3 \mathrm{~m}$, figure 2 , c.). Few days later, $\mathrm{N}$ waves propagated in the area (maximum $\mathrm{H}_{\mathrm{s}}=1.7 \mathrm{~m}$, figure 2, g.). During the $\mathrm{S}$ wave event, a shoreline retreat was observed in the southern part of the beach while the shoreline was moving seaward in its central and northern parts (figure 3, a.). During the $\mathrm{N}$ wave events, a shoreline retreat was monitored in the northern part of the beach while an advance occurred in its central and southern parts (figure $3, \mathrm{~b}$.). These patterns highlight a beach rotation controlled by wave direction. The banquette evolution follows a similar pattern. On the $\mathrm{N}$ transect, the banquette tend to reduce under the impact of $\mathrm{N}$ wave and to increase during the $\mathrm{S}$ wave event (figure 2.a., e.); the opposite is observed over the $S$ transect (figure 2.b., f.). Moreover, the banquette is destroyed on $S$ transect (figure 2, b., the 06/03/2016), suggesting beach washing and banquette removal when a threshold in wave height is reached ( $\mathrm{S}$ waves reaching $\mathrm{H}_{\mathrm{s}}=3 \mathrm{~m}$ in this case). This dynamics of banquette rotation and deposition/removal when the threshold of wave height is overtopped were monitored during other events on this site and on Meria beach.

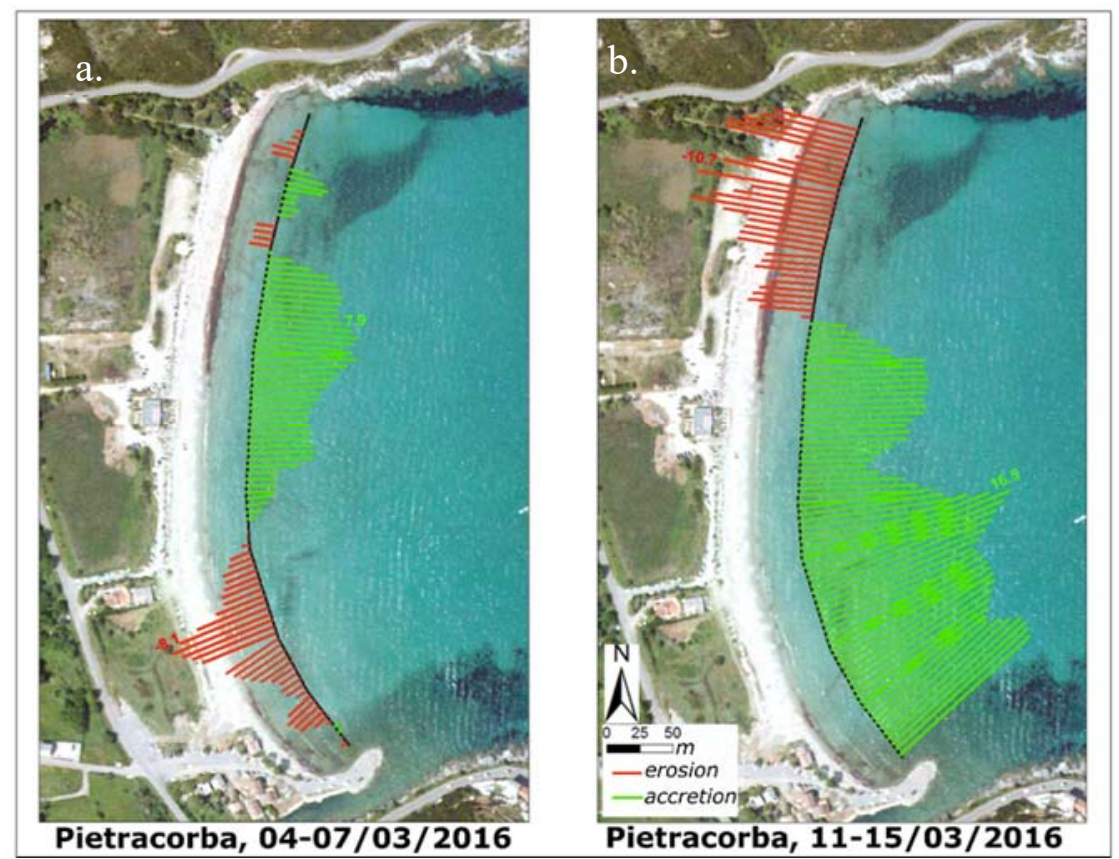

Figure 3. Shoreline evolution over the two periods compared (a.04-07/03/2016 and b.11-15/03/2016) at Pietracorbara beach.

While we observed a rotation of the banquette driven by wave direction under low wave energy conditions, GOMEZ-PUJOL et al. (2013) observed a destruction of the banquette under similar conditions but in larger scale semi-enclosed beaches (roughly $2 \mathrm{~km}$ long). An investigation of destruction parameters under low wave energy conditions seems to be needed, especially in regards of the beach opening index. 


\section{Thème 6 - Gestion durable des zones littorales et estuariennes}

\subsection{P. oceanica litter dynamics}

A threshold of banquette destruction also exists at Ostriconi beach but the banquette dynamics are different. A video computed from pictures taken between the 04/07/2016 and the $08 / 08 / 2016$ shows that P.oceanica fragments were transported by waves from the offshore to the beach in massive influx. The litter goes back to the offshore area through rip currents depending on wave conditions, and particularly on wave-induced tridimensional circulation cells.

\subsection{Protective role of the banquettes for the beach}

At Pietracorbara beach and Meria beach, waves were breaking in the surf zone (figure 4, white zones along the shore). Concomitantly, if litter was floating in the water, waves did not break (figure 4 , dark areas marked by black stars $\left(^{*}\right)$ ). These results indicate that floating litter tends to modify water viscosity and, consequently, wave breaking.

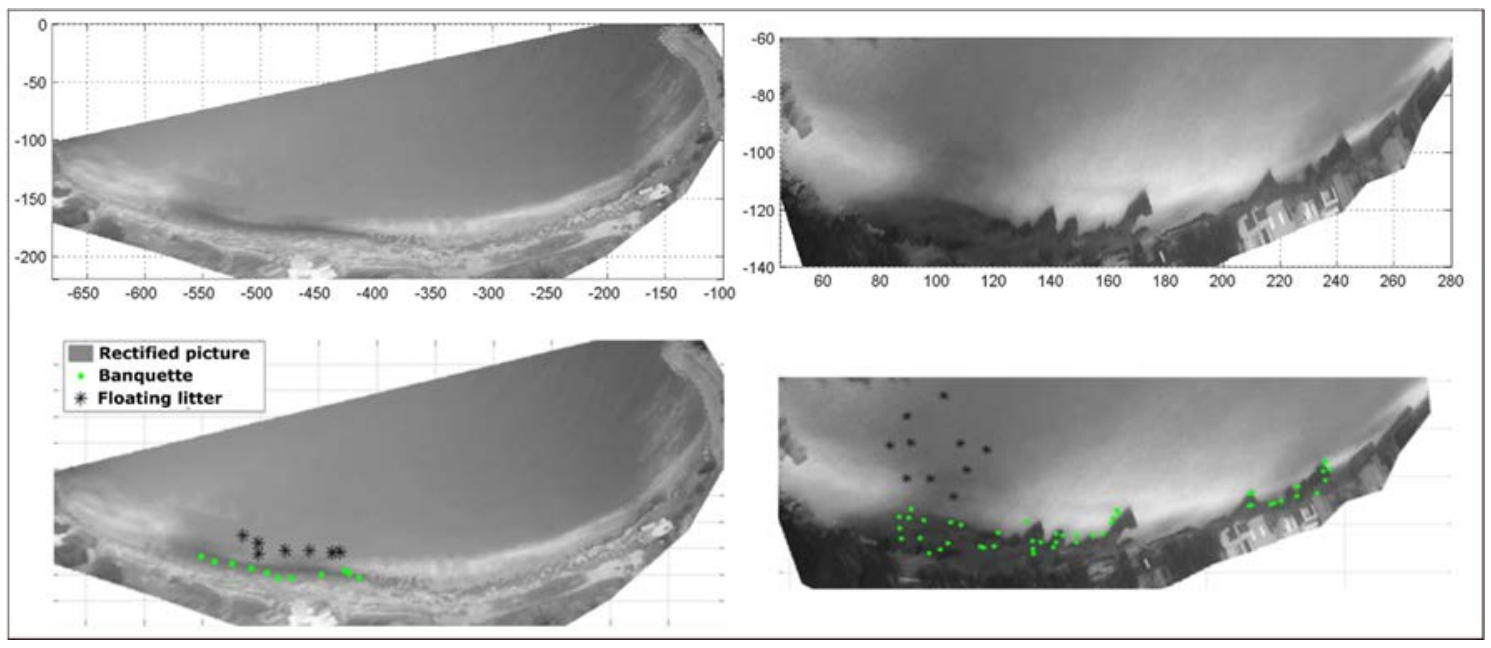

Figure 4. Rectified pictures of Pietracorbara beach taken on the 10/02/2017 (left) and Meria beach taken on the 23/04/2017 (right) before (up) and after (bottom) processing.

In addition, the presence of the banquette on the shore protects from erosion. The beach is protected until the threshold of wave height causing the banquette removal is reached. The destruction of the banquette in turn depends on its own characteristics (structure, compression, height, extent). The protective role of a banquette thus depends on the maximum wave height, the characteristics of the banquette and the duration of the event.

\section{Conclusion}

The measurements carried out on these three pocket beaches have shown the protective role of the $P$. oceanica litter in the water (modification of wave breaking) and ashore (buffer role of the banquette). The present results have also highlighted the banquette dynamics (banquette rotation, exchanges with the offshore, wave height threshold causing 


\section{XVI'̀mes Journées Nationales Génie Côtier - Génie Civil \\ Le Havre 2020}

the banquette destruction). Further measurements would be needed to confirm these results and further analyze local hydrodynamics' interactions.

These first results can still provide useful inputs to local administrators for beach management. However, MOSSONE et al. (2019) have shown that (1) $41 \%$ of the users have a negative perceptions of a beach covered of $P$. oceanica fragments and that (2) beach management policies are influenced by these negative opinions despite the interest of keeping the banquettes for beach protection. A reinforced and permanent work of sensitization is needed towards local and foreign beach users to convince them of the interest of a natural beach, possibly covered of $P$. oceanica fragments.

\section{References}

ALMAR R., BONNETON P., SENECHAL N., ROELVINK D. (2009). Wave celerity from video imaging: A new method. Proceedings of the Coastal Engineering Conference 2008, pp 661-673. https://doi.org/10.1142/9789814277426 0056

BALOUIN Y., MORRIS B. D., DAVIDSON M.A., HOWA H. (2004). Morphology evolution of an ebb-tidal delta following a storm perturbation : assessments from remote sensed video data and direct surveys. Journal of Coastal Research, Vol. 20-2, pp 415-423. https://doi.org/10.2112/1551-5036(2004)020[0415:MEOAED]2.0.CO;2

BALOUIN Y., BELON R. (2014). Evolution of Corsican pocket beaches. In: Green, A.N. and Cooper, J.A.G. (eds.), Proceedings 13th International Coastal Symposium (Durban, South Africa), Journal of Coastal Research, Special Issue No. 70, pp 96-101. https://doi.org/10.2112/S170-017.1

BOUDOURESQUE C.F., BERNARD G., PERGENT G., SHILI A., VERLAQUE M. (2009). Regression of Mediterranean seagrasses caused by natural processes and anthropogenic disturbances and stress: a critical review. Botanica Marina, Vol. 52, pp 395-418. https://doi.org/10.1515/BOT.2009.057

BRYAN K.R., FOSTER R., MACDONALD I. (2013). Beach rotation at two adjacent headland-enclosed beaches. Journal of Coastal Research, Vol. 65, pp 2095-2100. https://doi.org/10.2112/SI65-354.1

DE FALCO G., SIMEONE S., BAROLI M. (2008). Management of beach-cast posidonia oceanica seagrass on the island of Sardinia (Italy, Western Mediterranean). Journal of Coastal Research, Vol. 24-4c, pp 69-75. https://doi.org/10.2112/06-0800.1

GOMEZ-PUJOL L., ORFILA A., ALAVREZ-ELLACURIA A., TERRADOS J., TINTORE J. (2013). Posidonia oceanica beach-caster litter in Mediterranean beaches: a coastal videomonitoring study. Proceedings 12th International Coastal Symposium (Plymouth, England), Journal of Coastal Research, Special Issue No. 65, pp 1768-1773. https://doi.org/10.2112/SI65-299.1

HOLLAND K.T., HOLMAN R.A. (1997). Video estimation of foreshore topography using trinocular stereo. Journal of Coastal Research, Vol. 13-1, pp 81-87. https://www.jstor.org/stable/4298593 
MATEO M.A., SANCHEZ-LIZASO J.L., ROMERO J. (2003). Posidonia oceanica "Banquettes": a preliminary assessment of the relevance for meadow carbon and nutrients budget. Estuarine coastal and shelf science, Vol. 56-1, pp 85-90. https://doi.org/10.1016/S0272-7714(02)00123-3

MOSSONE P., GUALA I., SIMEONE S. (2019). Posidonia banquettes on the Mediterranean beaches: to what extent do local administrators' and users' perceptions correspond? In Planning, nature and ecosystem services, C. Gargiulo \& C. Zoppi (Eds.), Naples, FedOAPress, pp 225-234. https://doi.org/10.6093/978-88-6887-054.6

PERGENT G., BAZAIRI H., BIANCHI C. N., BOUDOURESQUE C.F., BUIA M.C., CLABAUT P., HARMELIN-VIVIEN M., MATEO M.A., MONTEFALCONE M., MORRI C., ORFANIDIS S., PERGENT-MARTINI C., SEMROUD R., SERRANO O., VERLAQUE M. (2012). Mediterranean seagrass meadows: resilience and contribution to climate change mitigation. A short summary. IUCN publ., Gland, Málaga, pp 1-40.

SIMEONE S., DE FALCO G. (2012). Morphology and composition of beach-cast Posidonia oceanica litter on beaches with different exposures. Geomorphology, Vol. 151-152, pp 224-233. https://doi.org/10.1016/j.geomorph.2012.02.005

SIMEONE S., DE FALCO G. (2013). Posidonia oceanica banquette removal: sedimentological, geomorphological and ecological implications. Proceedings 12th International Coastal Symposium (Plymouth, England), Journal of Coastal Research, Special Issue No. 65, pp 1045-1050.

THE WAMDI GROUP ${ }^{\circledR}$ (1988). The WAM Model - A third generation ocean wave prediction model. https://doi.org/10.1175/1520-0485(1988)018<1775:TWMTGO >2.0.CO;2

VALENTINI N., SAPONIERI A., MOLFETTA M. G., DAMIANI L. (2017). New algorithms for shoreline monitoring from coastal video systems. Earth Science Informatics, Vol. 10, pp 495-506. https://doi.org/10.1007/s12145-017-0302-x

VALENTINI N., BALOUIN Y., LAIGRE T., BOUVIER C., BELON R., SAPONIERI A. (2019). Investigation on the capabilities of low-cost and smartphone-based coastal imagery for deriving coastal state video indicators: Applications on the upper Mediterranean. Coastal Sediments 2019, pp 2635-2648. https://doi.org/10.1142/9789811204487_0226

VALENTINI N., BALOUIN Y. (2020). Assessment of a smartphone-based camera system for coastal image segmentation and Sargassum monitoring. Journal of Marine Science and Engineering, Vol. 8, 23. https://doi.org/10.3390/jmse8010023 